\title{
Election results: new President 1996
}

Dr R. E. Kendell has been successful in the recent election for President. Dr Kendell will take office during the Annual General Meeting in London on 10 July 1996.

Votes were cast as follows:

Hamid Ghodse $\quad 514$

John Gunn 899

Robert Evan Kendell $\quad 1260$

Vanessa Cameron

The Secretary

\section{Distinction awards: the system in Northern Ireland}

This information is current af the time of witting, and suporsedes that proviousty gotven in the Pyschictic Bulletin (Vol. 19, No.6, June 1995, p387).

The scheme is based on a system of peer review and is administered by the Distinction and Meritorious Service Awards Committee. The DMSAC advises the Department which consultants engaged in the Health Service should receive awards for professional distinction and in so doing seeks to ensure that no consultant fails to receive fair consideration and that the purpose behind the scheme is being fulfilled.

The Committee is appointed by the Head of the Department of Health and Social Services with the concurrence of the relevant Minister. Members are appointed in the first instance for three years on a rotational basis, with provision for re-appointment for a second term.

Vacancies occur at the end of each year when the Committee is reconstituted. The current membership is:

Chairman: Rt Hon Lord Justice R S Carswell Members: Professor $J \mathbf{M}$ Bridges

Dr Fiona Caldicott

Professor B M Hibbard

\section{Professor M Rosen CBE Professor R G Shanks Mr D D Smyth CBE Professor G W Johnston}

The lay Chairman is a senior lawyer who helps to ensure the system of selection is open and accountable to the public. The other members consist of three consultants from Great Britain appointed with a view to ensuring parity of standards throughout the United Kingdom; three are consultants from Northern Ireland who are of such standing as to have no personal interest in the allocation of awards; and one is a second lay member and is currently the General Manager of the Northern Health and Social Services Board.

The DMSAC receives nominations with citations from a number of sources including the four area Boards, the Royal College of Psychiatrists and a local Award Holders' Panel (to which all award holders are invited) chaired by the Senior Award Holder in the province. Currently 23 of 72 consultant psychiatrists (32\%) in Northern Ireland have an award.

Chairman, Award Holders' Panel, July 1995 